\title{
ISLAND LIFE: A REFLECTION DURING THE COVID-I9 PANDEMIC
}

\section{Alun Roberts}

Islands. There's something about them. The fact that you're surrounded by water has a subconscious effect on you. You feel part of a close-knit community, all living in a limited space where the sea can play a major role in what you do and how you think.

Imagine that you live on an island, off an island. Well, that's Ynys Cybi for you (Cybi's Island or 'Holy Island' as it's better known in English). It is a small island, 15 square miles in size, which lies off the coast of the Isle of Anglesey in North Wales, UK. Anglesey lies off the coast of the UK mainland and is joined by two bridges - the Menai Suspension Bridge and the Britannia Bridge. Holy Island is a stone's throw to Anglesey and a short bridge, and two causeways make that important connection to the big world.

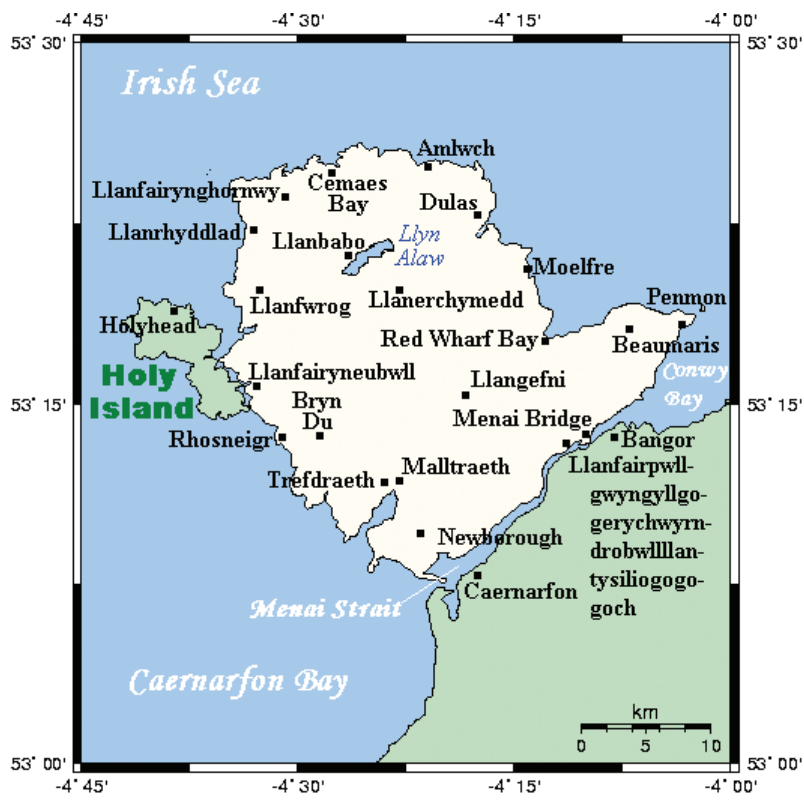

Figure I. CJ Moss (Kelisi), A map showing the Isle of Anglesey/Ynys Môn and nearby areas.

This map's source is at http://www.ifm-geomar.de/ifm-geomar/, with the uploader's modifications, and the

GMT homepage says that the tools are released under the GNU General Public License.

GNU Free Documentation License, Version 1.2 licence. 
Living on an island does bring that something extra into the way you think and act. There's no doubt that people feel connected to each other. That community spirit which we all crave for is to be found by the bucket load especially in the port town of Holyhead-which dominates Holy Island. For a town of population of 10,000 it feels more like a village - where everyone knows each other by sight, familial ties or kith or kin, but may not necessarily know each other's names.

That community spirit - felt subconsciously but not always seen - is something which comes to the fore when the chips are down. Disasters which befall individuals in the town are met by an outpouring of people wanting to help. Crowdfunding for funerals, volunteering for a range of organisations, raising money to send young people on summer camps - these are just a few examples of what a real community does for itself.

Whilst there are challenges for all communities dealing with the effects of COVID-19, it is people looking out for each other which enables a pandemic to be tackled head-on and brighter futures experienced as the collective will to survive prevails.

The challenges which COVID-19 has brought to Holy Island have been difficult to face - with the island's tourist trade badly hit as visitors are unable to travel to enjoy the island's beaches and spectacular scenery - that peace and tranquillity which normally provides a retreat from the fast pace of modern life.

This effect of fewer visitors on the economy has been felt alongside the impact on the ability of health professionals to deliver a service during unprecedented times.

The island has three general doctor practices and they have soldiered on in trying times to provide that level of support for patients who are trying to cope with a totally new phenomenon which the COVID-19 pandemic has thrust upon us. The programme of immunisation which started in 2020 has been in full flow for some time and it is remarkable to see such a behemoth of a machine - the UK'S National Health Service - kick-in to full 'military planning mode'. Seeing the regimented line of adults patiently waiting at the local cottage Hospital in Holyhead for their Pfizer jab - sometimes outside in the pouring rain, is a site to behold.

Whilst the town has seen about eight residents succumb to the dreaded virus, we have all come together to look after our friends, neighbours, and often complete strangers. The willingness of people to give their time freely to support food banks, collect and deliver medicines for the isolated and vulnerable and a desire generally to make the best of a bad situation, gives one a warm glow feeling inside.

With restrictions imposed by our Government likely to ease from now on, the sight of cruise ships starting to arrive back in Holyhead port is an indication of some semblance of normality returning. Whilst the cruise ship passengers disembarking and joining buses to tour the local area need to wear their masks, the fact they're here at all is a blessing, an economic blessing. Islands rely heavily on the spending power of tourists and their return is something we all welcome. 


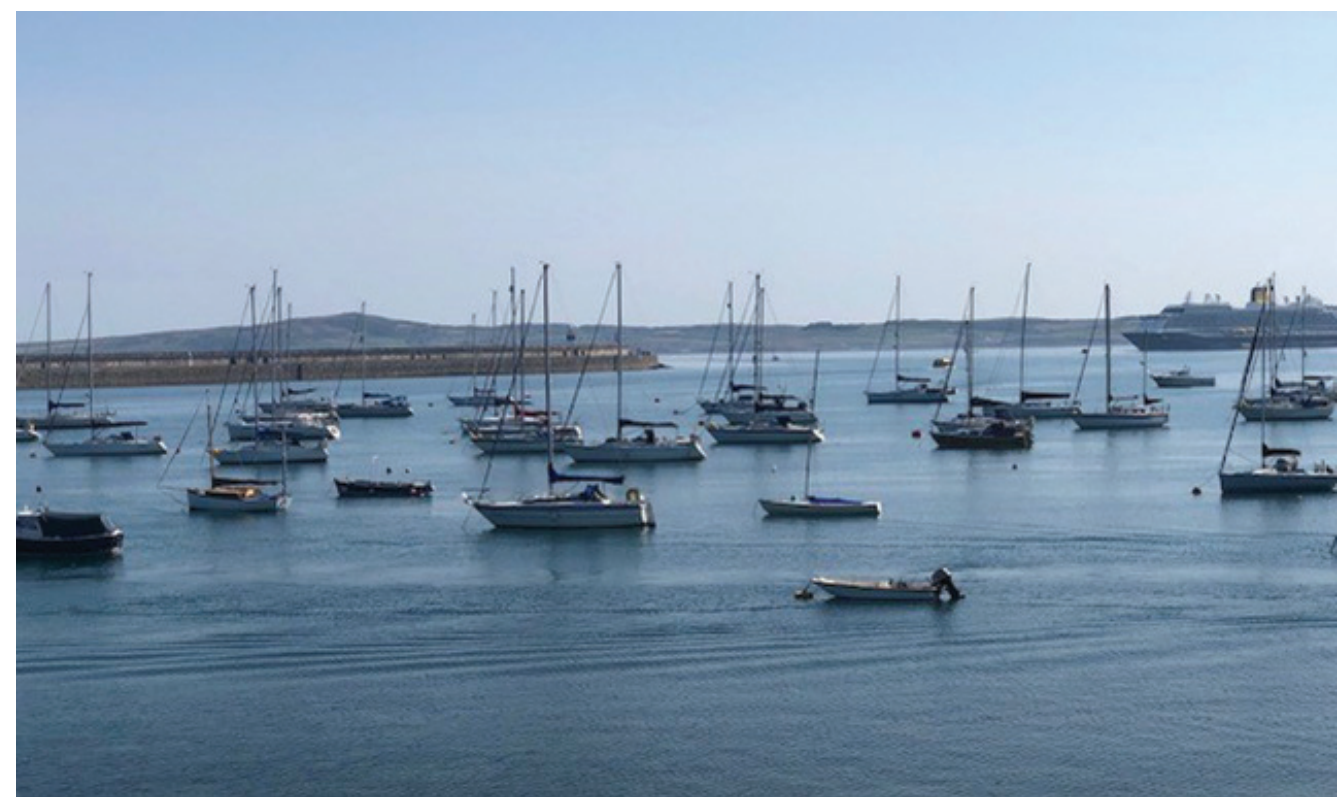

Figure 2. Cruise ship travelling through Holyhead harbour. Source: Author

With the school Summer holidays upon us there is that belief that we can see the light at the end of this pandemic tunnel and life will return to normality soon. There is a great deal of hope that children of school age will be able to resume their education in September 2021 without the restrictive controls of mask wearing and self-isolation which has been a curse for both teachers and pupils in the last few months.

Patients who have had surgeries and treatments postponed because of the focus on the pandemic are nervously waiting for news on when they will be seen or treated. The Health Service which has ensured we have been vaccinated is also buckling under the huge increase in hospital waiting lists and this situation will take unprecedented action to rectify. It is in difficult times that you realise the value we place on our health professionals and the demands placed upon their dedication and passion to make a difference in people's lives.

Public houses, restaurants, and hotels are nervously waiting to see if they can cope with the new demands placed upon them and their staff as the tourist season swings into action. Staff are hard to find for the hospitality industry in the United Kingdom now and Holy Island is not immune to this situation. Lockdown has made people think about their lives and for many they have decided to change careers. Many have opted not to work in demanding occupations such as bar and in the hospitality industry. Employers are struggling to recruit staff and have had to increase wages they pay staff to ensure they turn up for work. Interesting times indeed.

Island life goes on apace and people will come to appreciate how resilient they've been in facing these challenging times head-on. We'll all look back at this journey and be thankful that we survived this onslaught on our personal and communal lives. 
Alun Roberts, BA Business Administration was brought up in a small seaside village on the west coast of the Isle of Anglesey. He attended the local high school and progressed to higher education at the local university in Bangor. He did a BA degree through the medium of Welsh (which is his first language). His first proper job after university was as the Tourist Information Officer for the local authority in Anglesey. This gave him an excellent grounding and understanding of his home county. After a couple of years, he went into private business running an agency which offered self-catering accommodation within 800 properties on the Isle of Anglesey. Later he moved to work for a company in the construction industry as a commercial sales director before entering the world of supporting people who were struggling to find work. Over the previous 25 years he has been employed by a number of organisations such as Bangor University to utilise his local knowledge to support people into work or to establish new business ventures. He Chairs the only business forum in the county (Holyhead) and is a regular consultee in respect of community and business development in the county.

Correspondence to Alun Roberts. Email: alun@moncf.co.uk 